\title{
THE OUTLOOK FOR GROUND-WATER RESOURCES IN TEXAS
}

By

R. W. Sundstrom, District Engineer

Ground Water Branch, United States Geological Survey

1 Presented at the Southwest Section, American Water Works $A$ isociation, El Paso, Texas, October 20, 1954. Release authorized by the Director, United States Geological Survey. Prepared in cooperation with the Texas Board of Water Engineers. 


\title{
THE OUTLOOK FOR GROUND-WATER RESOURCES IN TEXAS 1
}

\author{
By \\ R. K. Sundstrom, Di strict Engineer \\ Ground Hater Branch, U. S. Geological Survey \\ October 1954
}

\section{INTRODUCTION}

The future of ground-water supplies in Texas presents a problem that is very important to the economy of lexas and to the well-being of almost every citizen of the State. It is of particular importance to more tilan 580 municinalities using ground water as the sole source of water supply; to many thousands of famers using ground water for irrigation an! al so to others living in irrigated areas or tepen lent on i rrigated agriculture for their livelihood; to more tian 2 million people living in rural areas who are denendent on $ॄ$ round water for doinestic supply, and to a large number of the industries hrouphout the state, including some of the Ligrest ones.

In 1953 more ground water was used in Texas than in any other State in the Pation, ui tis tile sole exception of Ćalifomia. According to tine available information, gathered irom anv sources, in the offices of tie $\therefore .5$. eoloçical survey and the lexas ?oard of ater winteers, the total use of ground water in jexas in 1953 is estimated to have been ciout ?, viv,, 06 acre-feet. The ariount of ground water now Leing used in lexas is nearly erual to the anount of surface water used for irrigation, inclustrial purposes, muni aipal use, anc rural conestic supnly. Of the fround water usec in 1953, about 83 percent of the total was used for irrigation, aiout 16 percent for industrial nurposes, about 4 percent for municisal supply, and about 3 percent for rurpl dorestic supply and livestock. Figure l sious grapinically the distribution of the use of ground water in 1953.

The increase in the use of groutd water is coincic'ental wi th the increase in populaticn, the increase of irrigatec! faming, the increase in industry, and the general growti of the econony of the State as a whole. In the irrigated areas of the State, the drought of the last 10 years has caused a considerable increase in the use of ground water and it has al so that some effect on tine use of water by inunicipalities.

1/ Presented at the Southwest Section, American Hater Horks Associatior, El Paso, Texas, October 20, 1954. Release authorized by the Director, United States Geological Survey. Prepared in cooperation with the Texas Board of hater Engineers. 


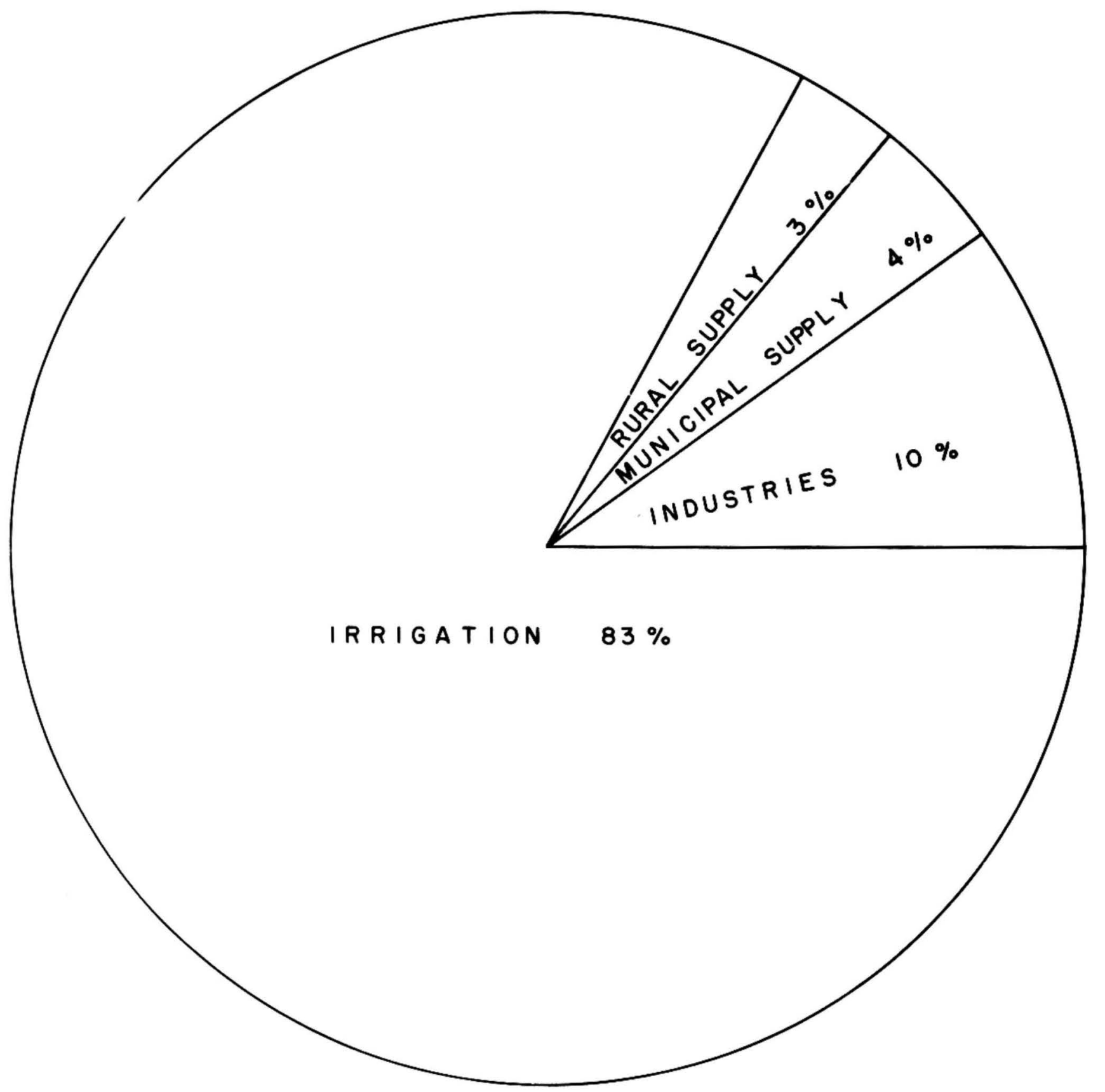

FIGURE I

COMPARATIVE USE OF GROUND WATER IN TEXAS, 1953 
Over a period of 100 years, the statistics of the Census Bureau show that the urban population of Texas has grown at a somewhat steady rate from less than 8,000 in 1850 to more than 4,800,000 in 1950, increasing at the same time from $3 \frac{1}{2}$ percent to 63 percent of the total population of the State. Figure 2 shows the growth in total population and the distribution in growth among the rural and urban population. It should be noted that there were no Texas cities of more than 100,000 population in 1930 and that the urban population increased by 60 percent during the decade from 1940 to 1950, most of the growth being in cities above 10,000. Almost every city in Texas of more than 10,000 has had "growing pains" in expanding its public water suppiy since 1940. The city without a water-supply problem has been the exception rather than the rule. This problem also faces the irrigators in many of the heavily irrigated areas the industrialists involved in the rapid expansion of Texas industries, and the rural farmer who has gone through 10 years of drought and wonders whether or not he can economically develop ground water to grow crops or water his livestock. An epidemic of "water consciousness" is spreading over Texas

As you will note in figure 1,83 percent of the ground water now pumped is used for irrigation. Figure 3 shows the increase in ground-water irrigation, by acres irrigated; from 1919 through 1949 as compiled by the U. S. Department of Agriculture, and later figures compiled from information in the office of the Board of Water Engineers and the Geological Survey. Quantitative figures on the amount of ground water used for irrigation prior to 1937 are meager. Recent studies indicate that the amount of ground water applied varies from less than 1 to more than 3 acre-feet. per acre. The chart does indicate however, that the overall use of ground water was rather limited until 1939. From 1939 to date ground-water irrigation has developed at a tremendous rate. Of the total amount of ground water used in 1953, about 4.800,000 acre-feet or 69 percent was pumped in the High Plains of Texas

\section{THE HIGH PLAING}

During 1953, about 6,000 wells were drilled in the High Plains, 35 percent more than during the preceding 2-year period 1951-52, and of these wells more than 85 percent were drilled in the principal irrigated region of the southern High Plains. By the end of 1953, about 24,500 wells in the High $\mathrm{Plains}$ were in use or available for use, of which 93 percent, or 23,000 were in the principal irrigated region. Of the remaining 1,500 wells, about 1,000 were in the more southerly counties of the High $\mathrm{Pl}$ ains and about 500 in the North Plains. The area irrigated in the principal irrigated region increased from 2, 150,000 acres in 1952 to 2,900,000 acres during 1953 (fig. 4). 


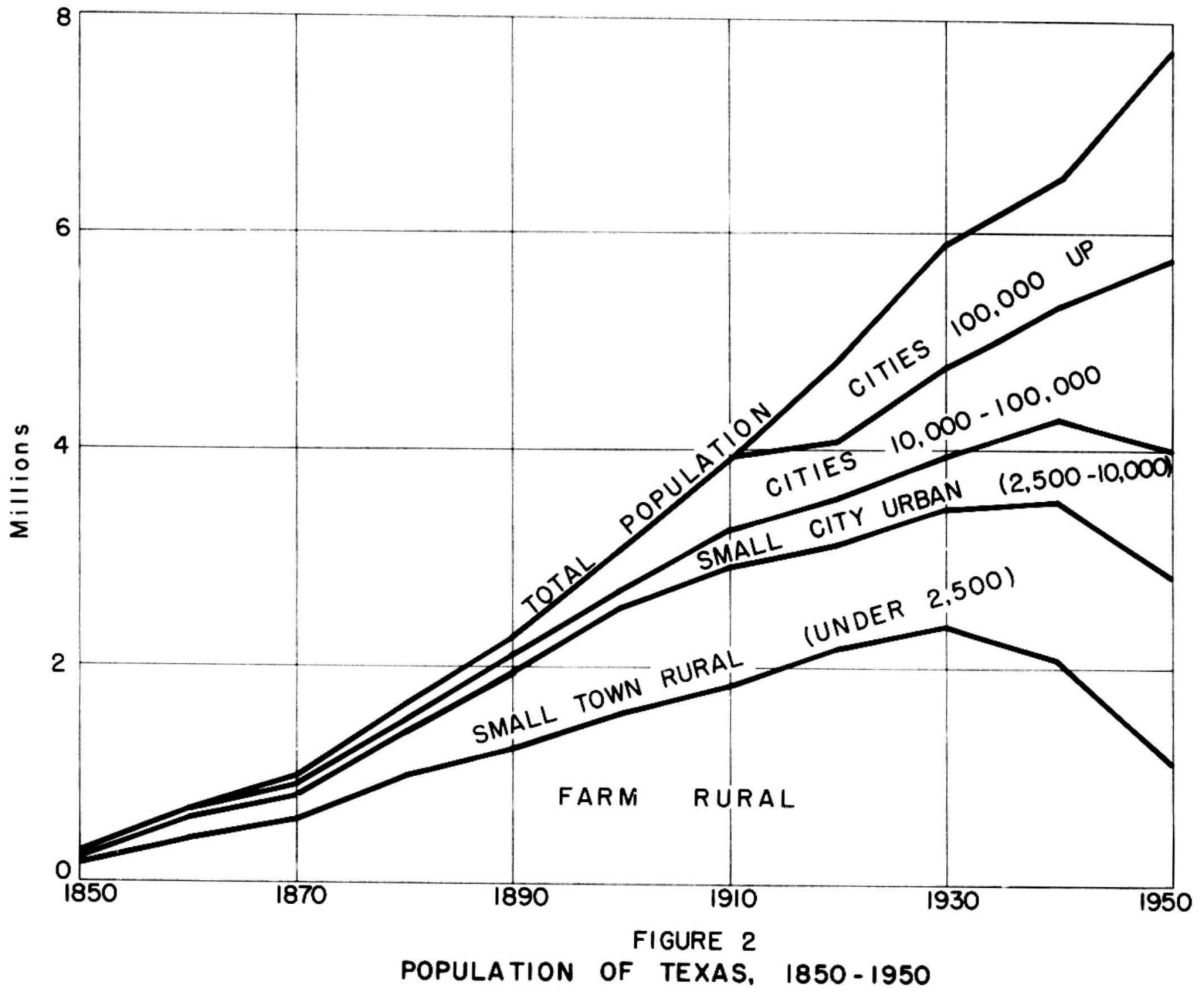

$\rightarrow$ 


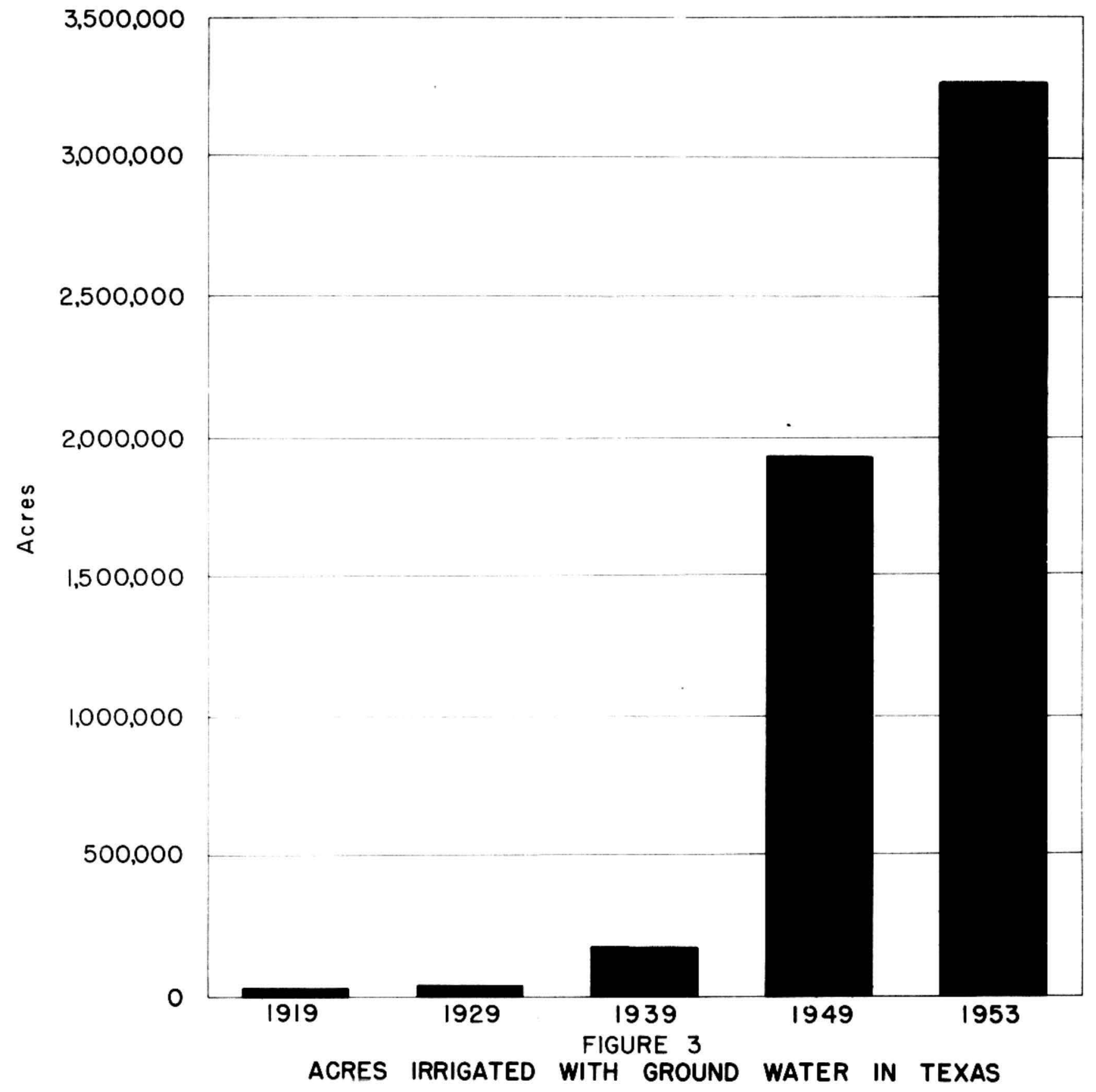

G 
Estimates of the withdrawals of ground water in the High Plains are based on the number of acres irrigated the duty of water per acre, including rainfall, and the operating time as obtained from data on consumption of electricity.

Since 1938 the withdrawals of ground water from the Ogallala formation, the principal water-bearing formation of the High $\mathrm{Pl}$ ains, have increased each year except during those periods (principally 1941) when precipitation was above nomal and the demand for water for irrigation was relatively light. Owing in part to drought conditions, the withdrawals of ground water for irrigation municipal domestic and industrial supplies in the High Plains increased from an estimated $3,750,000$ acre-feet in 1952 to approximately 4,800,000 acre-feet in 1953, or about 28 percent. Of the pumpage in 1953, approximately 90 percent or 4300,000 acre-feet was wi thdrawn in the principal irrigated region an increase of about 1, 100000 acre-feet About 75,000 acre-feet, or about 2 percent of the total was withdrawn for municipal and industrial use.

Since 1938 to the end of 1953 approximately 16 million acre-feet of ground water was pumped in the High Plains of which more than 60 percent was pumped during the period 1950-53. Assuming that water equivalent to about 15 percent of the total volume of the formation is yielded to wells, the wi thdrawals of ground water in 1953 unwatered 32 million acre-feet of saturated materials and the wi thdrawals since 1938 have unwatered about 105 million acre- feet

Water levels measured in a network of about 500 observacion wells in January, February, and March before pumping begins. provide the basis for estimating the net ioss or gain in storage for each year of operation Prior to 1943 irrigation was concentrated in relatively small areas and the declines of the water levels in wells were confined largely to those areas Since 1943 however, irrigation has spread out to form one large district which is the principal irrigated region in the southern High Plains and embraces all or parts of 19 counties

Contours of water-level declines in the "igh Piains from January 1953 to January 1954 are shown in figure 5 The map shows that the areas in which the decline was 2 feet or more has spread out to form one large area embracing about 4,200,000 acres. On the basis of the average decline within each county, the total net amount of makerial unwatered was determined to be $28,000,000$ acre-feet. The loss in storage, assuming a specific yield of 15 percent is $4,200,000$ acre-feet

This total checks very well wi th the figure of 4,300 000 acre-feet derived from the pumpage inventory. It shows that the assumed figure of 15 percent for specific yield is very close to the true value. It shows also that the great bulk of the water pumped in 1953, like that in previous years, was derived from storage 


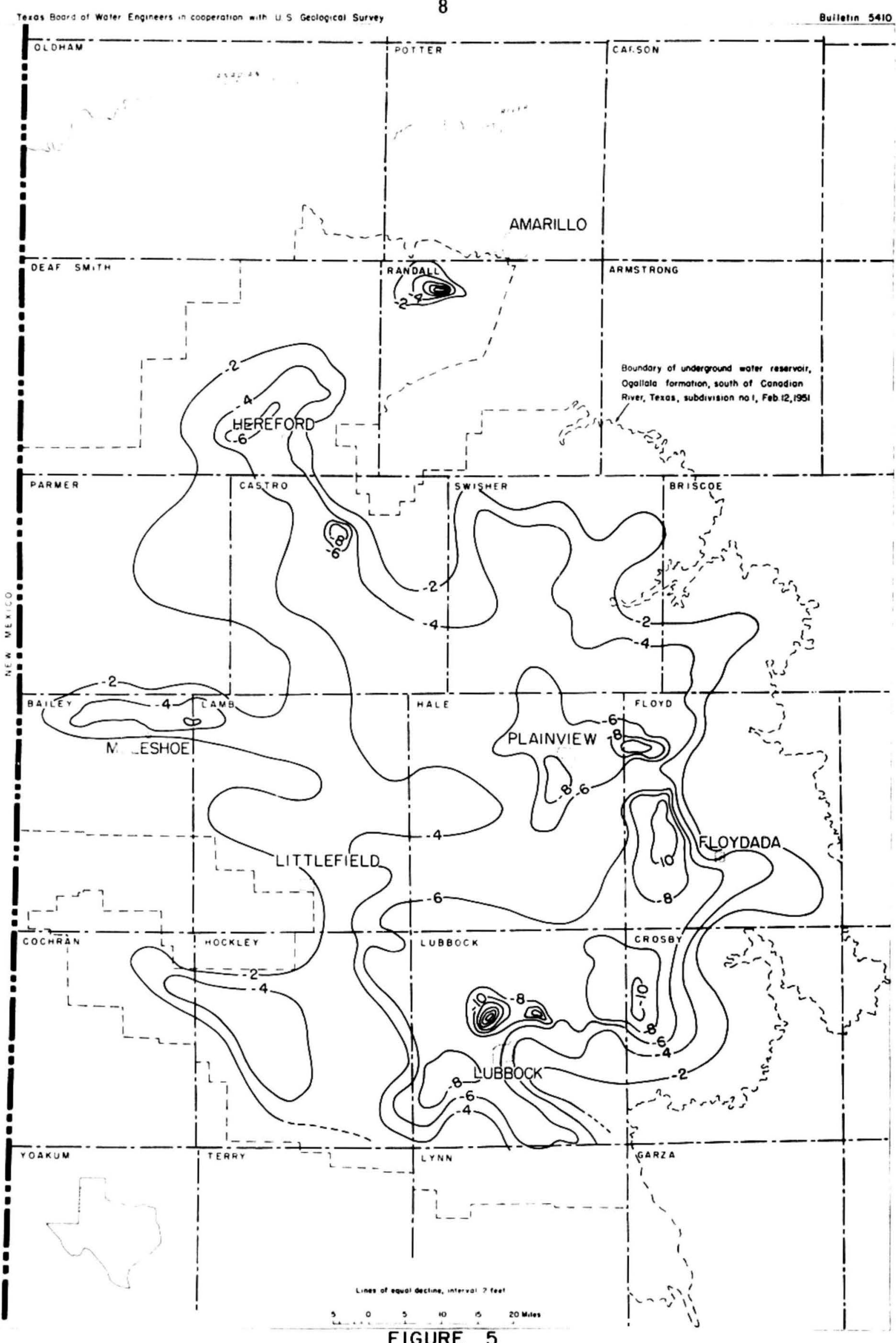

FIGURE 5 
It shou'd be emphasized that the decline from 1952 to 1953 represents just one year, and that it is piled on top of similar though snaller declines in each of the several preceding years. As the water levels decline it becomes increasingly important to regard the declines in water levels in terms of the thickness of the remaining saturated material. Areas such as those in the southern part of Lubbock County and southeast of Plainview, where the Ogallala formation is relatively thin, can be expected to experience diminishing yields sooner than the areas where the saturated sands are thicker.

Al though it is known from available data that the total amount of ground water in storage beneath the $\mathrm{High} \mathrm{Plains}$ as a whole is several hundred million acre-feet, the high rate of wi thdrawal poses a serious problem not only to the irrigators in certain parts of the area but also to the town and cities in the area. Looking ahead, the cities of Amarillo and Lubbock have acquired water rights beneath more than 100.000 acres in areas where irrigation is not now being heavily practiced. Other cities are considering similar plans and still others are giving consideration to the development of surface water from the Cano dian River

Studies of the ground-water resources of the High $\mathrm{Plains}$ have been under way for many years, but there is still a dire need for additional water facts to provide a basis for intelligent planning by the users of ground water Such a fact-finding survey should include:

1. Study of the Ogallal a fomation the principal ground-water reservos $r_{\text {, }}$ and $i$ ts relation to the occurrence of ground water throughout the High $\mathrm{Plains}$, with emphasis on areas not touched by previous studies

2. Detemining the approximate thickness of the Ogallal a throughout the High Plains.

3. Letemining the approximate amount of ground water that has been removed from storage and the amount of ground water that still remains in storage in the Ogallala formation throughout the $\mathrm{High} \mathrm{Pl}$ ains.

4. Study of the capacity of the ground-water reservoir to yield water to wells throughout the High $\mathrm{Pl}$ ains.

5. Study of the extent of the present development of ground water in parts of the High Plains where such a study has not been made.

6. Study of additions to the ground-water reservoi $r$ through recharge throughout the High Plains.

7. Determining the chemical quality of the ground water in parts of the High $\mathrm{Pl}$ ains where such work has not been done

8. Inventory of the pumpage from the ground-water reservoi $r$ throughout the High $\mathrm{Pl}$ ains.

9. Collecting all basic data pertaining to existing welis.

10. Expanding the present observation-well program so that a more accurate estimate can be obtained each year of the withdrawal from storage in the ground-water reservoir. 
11. Preparing and releasing to the public of comprehensive reports giving the results of these studies, along with the useful basic data collected

These data are indeed essential in detemining the potential of the High $\mathrm{Plains}$ ground-water reservoir and the amount of water available for future use. Data of this nature, modified as necessary in some cases to be applicable to the particular ground-water reservoir, are needed for other ground water reservoirs in Texas.

It is impossible in the space allotted for this paper to discuss even in brief detail the present development and the potential water-yielding characteristics of the many other ground-water reservoirs that have recei ved some study. However, I should like to highlight some of the present development in widely scattered areas such as Houston San Antonio and El Paso

\section{HOUSTON AREA}

For the Houston area figure 6 shows the rate of development of ground water in the llouston Gulf Coast region - the coastal $\mathrm{plain}$ area between the Brazos and Trinity Rivers extending to the northern boundary of Waiker County for the period 1889 to 1953. The chart shows a greatly accelerated rate of development of ground water since 1937 Also of interest is the more steady rate of climb in the use of ground water for municipal purposes as compared to ground water use for industries and the growing of rice. Figure 7 shows the decline in artesian pressure that has occurred in wells in the most heavily pumped portion of the area since 1932 Figure 8 shows how the cone of artesian-pressure decline has spread as a result of the heavy pumping in the Houston-Pasadena area The artesian head in the center of this cone has de. clined about 300 feet from the original head of the ground water reservoi $r$ before pumping began. This particular chart might indicate a serious problem to the casual observer. The facts of the study however riveal that with the exception of problems of overoncentration of pumpage and the possibility of eventual sal t-water intrusion in the southern part of the area the area as a whole can produce several times the amount of ground water now being wi thdrawn

Figure 9 shows a generalized section of the area fron, northwest to southeast illustrating the underlying material and the approximate contact of fresh and salty water.

Figure 10 is a map showing the depths to which fresh-water sands occur in Harris County. It is evident from this map that fresh water sands occur to a depth of as much as 2,000 feet in most of the oounty and as much as 3000 feet in a smaller portion. 


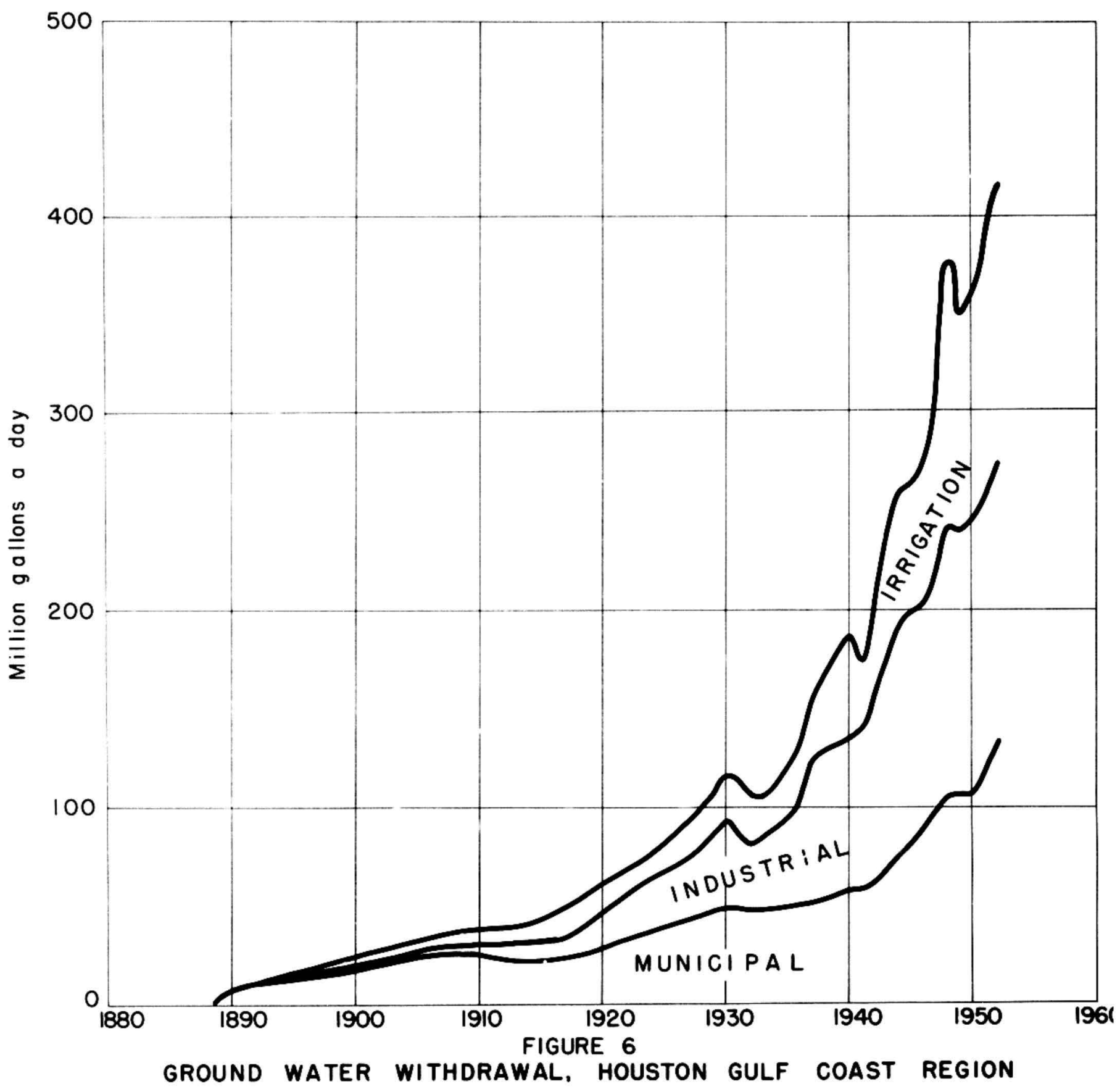




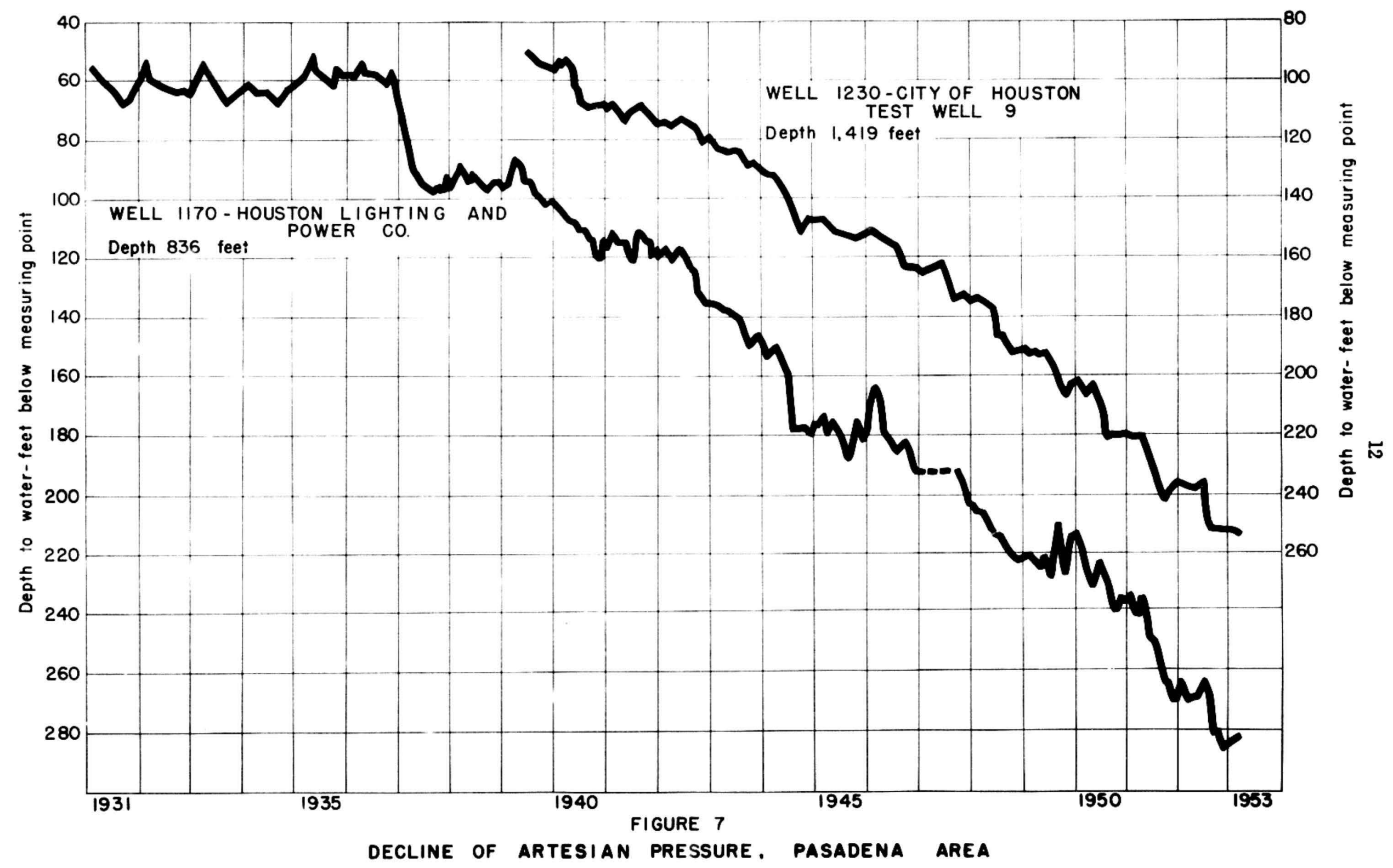




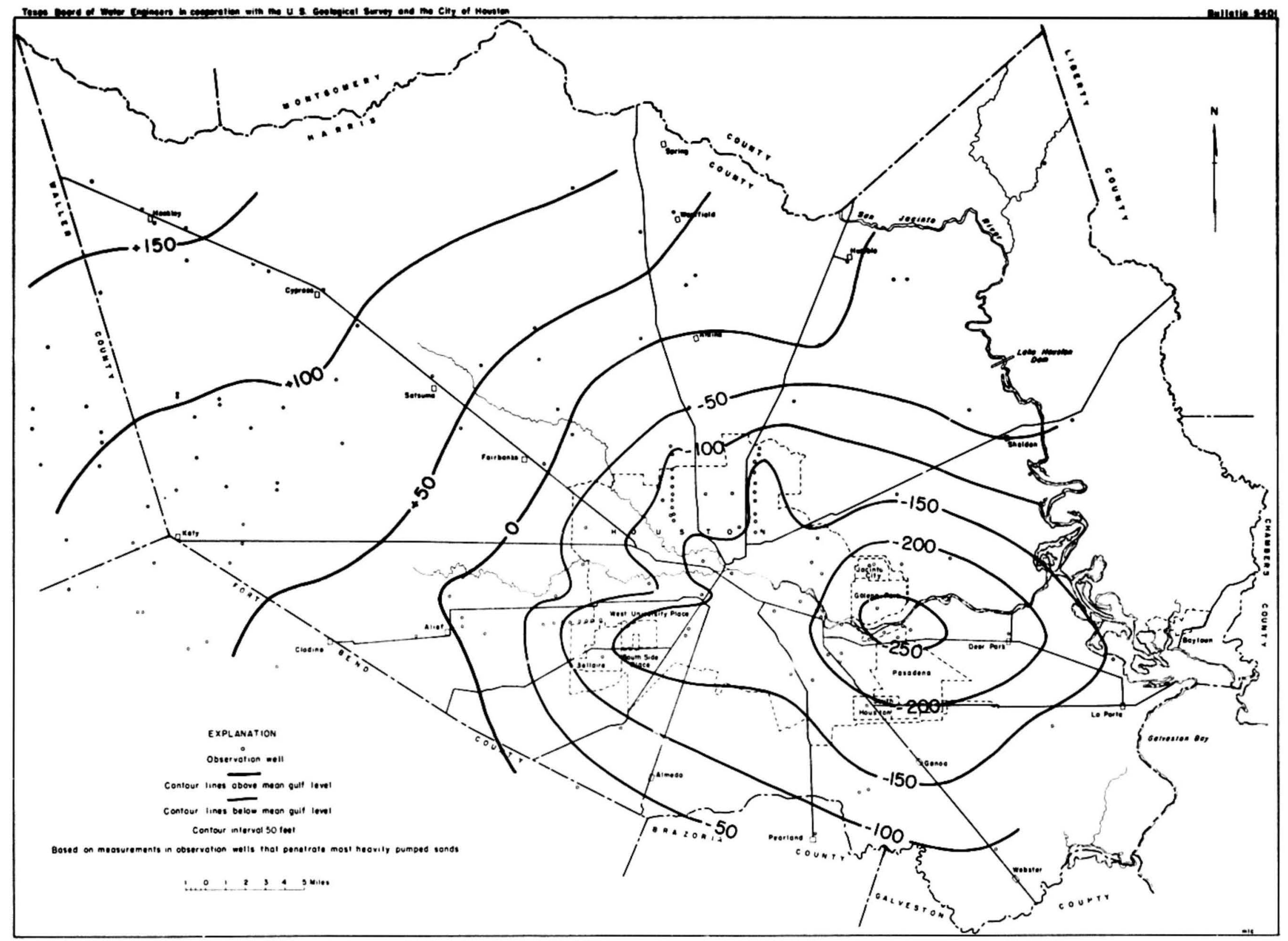


A

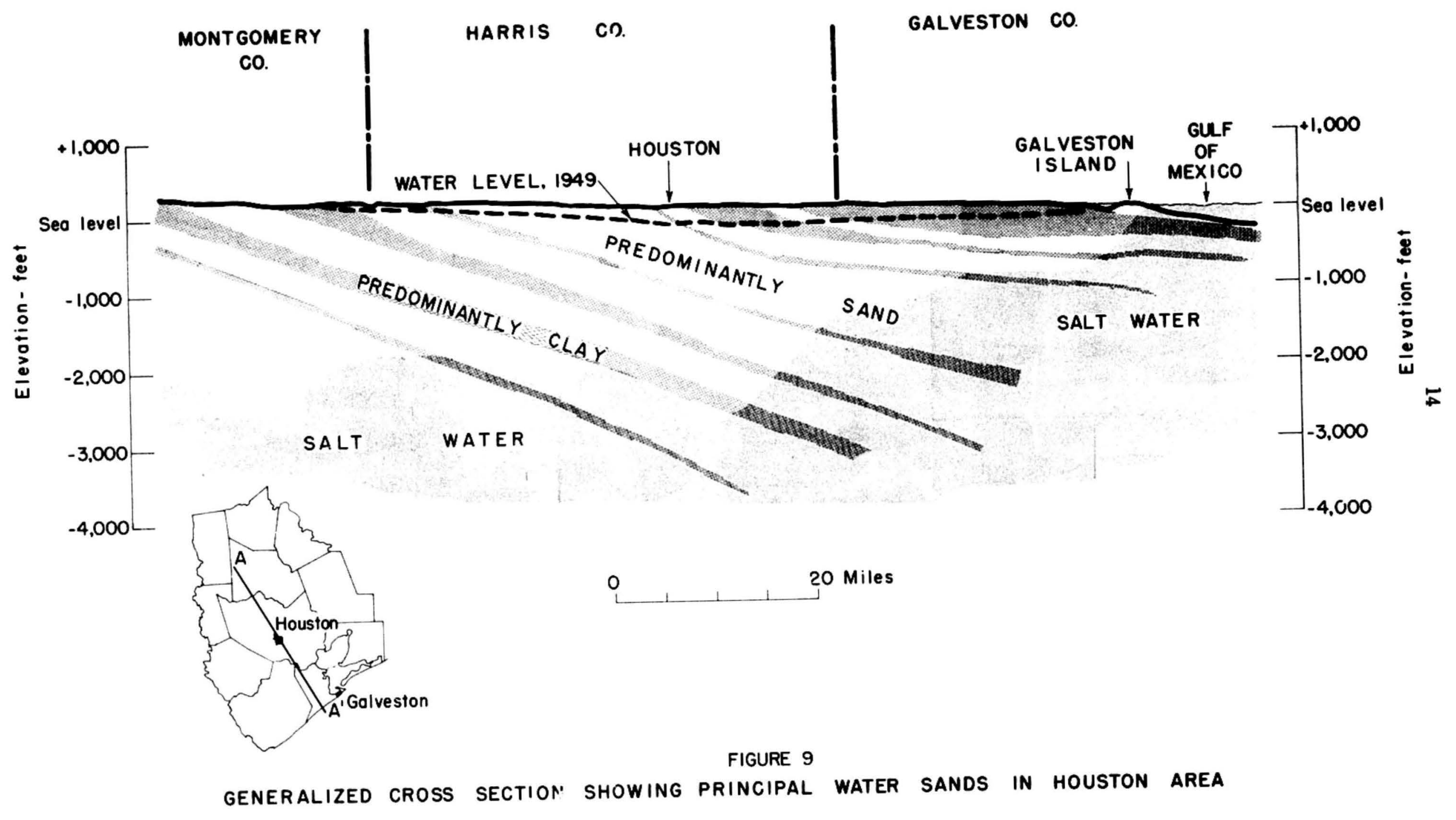




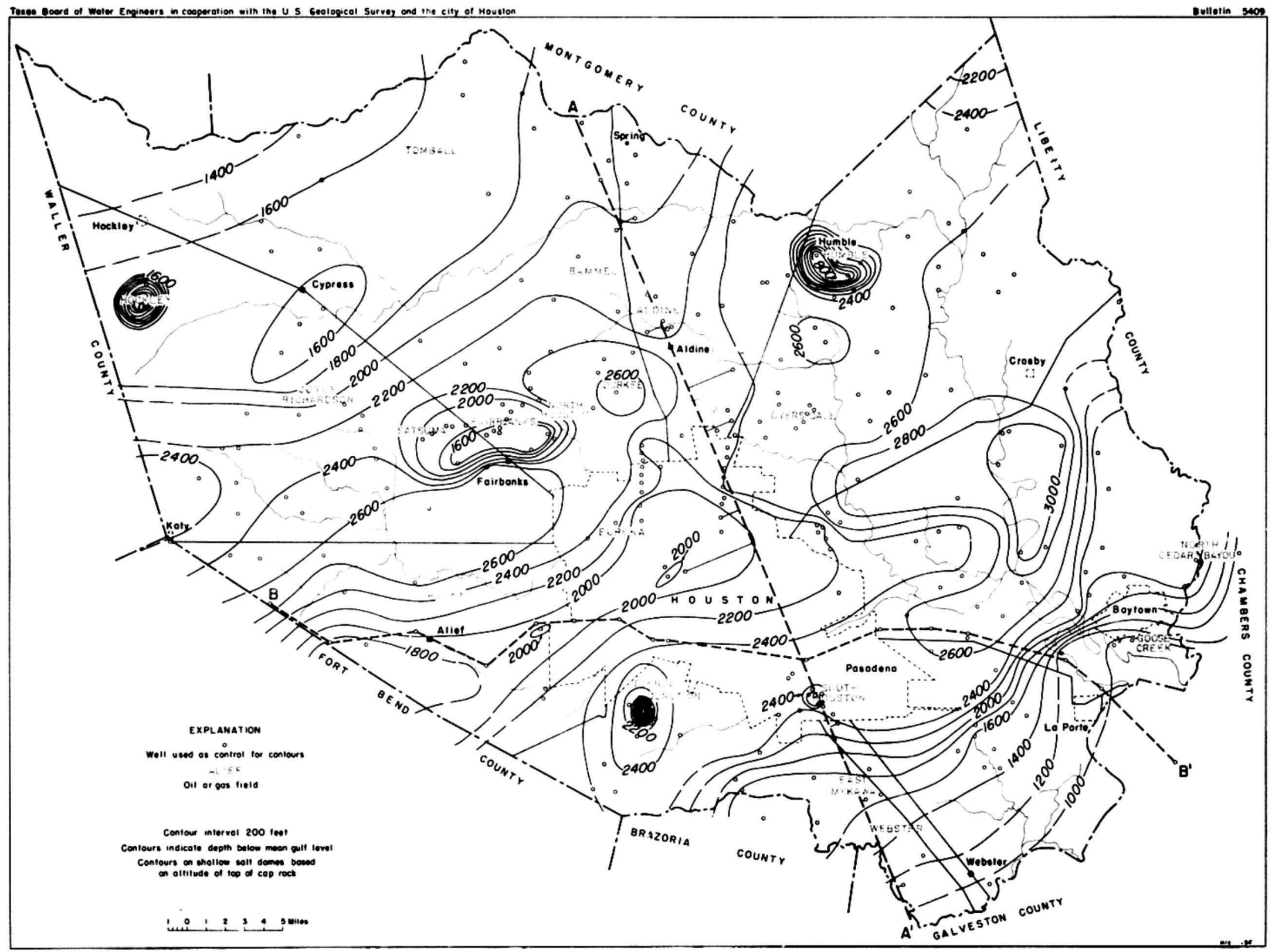


Harris County occupies an area of 1,730 square miles For the purpose of illustrating the amount of fresh ground water beneath Harris County, let it be assumed that the average depth of fresh water is 2,000 feet and that the porosity of the material ranges from 20 to 40 percent and averages 30 percent Then it can be computed that 1.730 square miles times 640 , to change the area into acres, times 2000 feet aquals more than 2 billion acre-feet of saturated material. or more than $650 \mathrm{million}$ acre-feet of water, if the average porosity is 30 percent. This figure has little value in determining the amount of ground water that could be pumped in Harris County owing to the great depth at which the water occurs Arte.* sian pressure must be maintained to force the water from the deeper sands into the wells so that the water can enter the pumps at a higher altitude These deep sands do, however, have great importance as conduits to the wells, and modern hydrology can be employed in ascertaining within a reasonable degree of accuracy the quantity of water than can be recovered. To get the ultimate yield from this or any other ground-water reservoir would require regional development based on sound application of the principles of ground-water geology and hydrology

\section{SAN ANTONIO AREA}

Figure 11 shows the growth in the development of ground water by the city of San Antonio. The chart gives clear evidence as to the nature of the water problem that the city of San Antonio is now facing At the present time San Artonso is obtaining all of its water from the Edwards limestone.

The Edwards limestone aquifer forms two immense ground-water reservoirs in the San Antonio area - one an unconfined water body on the Edwards Plateau in the northern part. and the other an artesian water body in the main Balcones fault zone. The hydrologic system on the plateau stores substantial amounts of rainfall and slowly pays it out as spring flow to the perennial streams which have cut their channels into or through the aquifer The streams furnish practically continuous recharge to the artesian reservoir in the Balcones fault zone as they cross long stretches of honeycombed and cavernous limestone, into which the entire normal flow is lost Thus the artesian reservoir not only has its own storage facilities, but also receives benefits of storage and regulation afforded by the system on the Edwards Plateau In addition, recharge occurs also by direct penetration of rainfall and storm runoff in the favorable outcrop localities in northern Bexar Medina, and Uralde Counties

Results of studies suggest that the immense artesian reservoir within the belt of faulting is a common source for the large springs (including Comal Springs at New Braunfels) and several thousand wells in the San Antonio area The discharge of the springs, the flow of the wells and springs in and near San Antonio, and the water levels in the nonflowing wells throughout the area vary with the volume of water in the reservoir. The magnitude of the reservoir is indicated by the uniform temperature and lack 


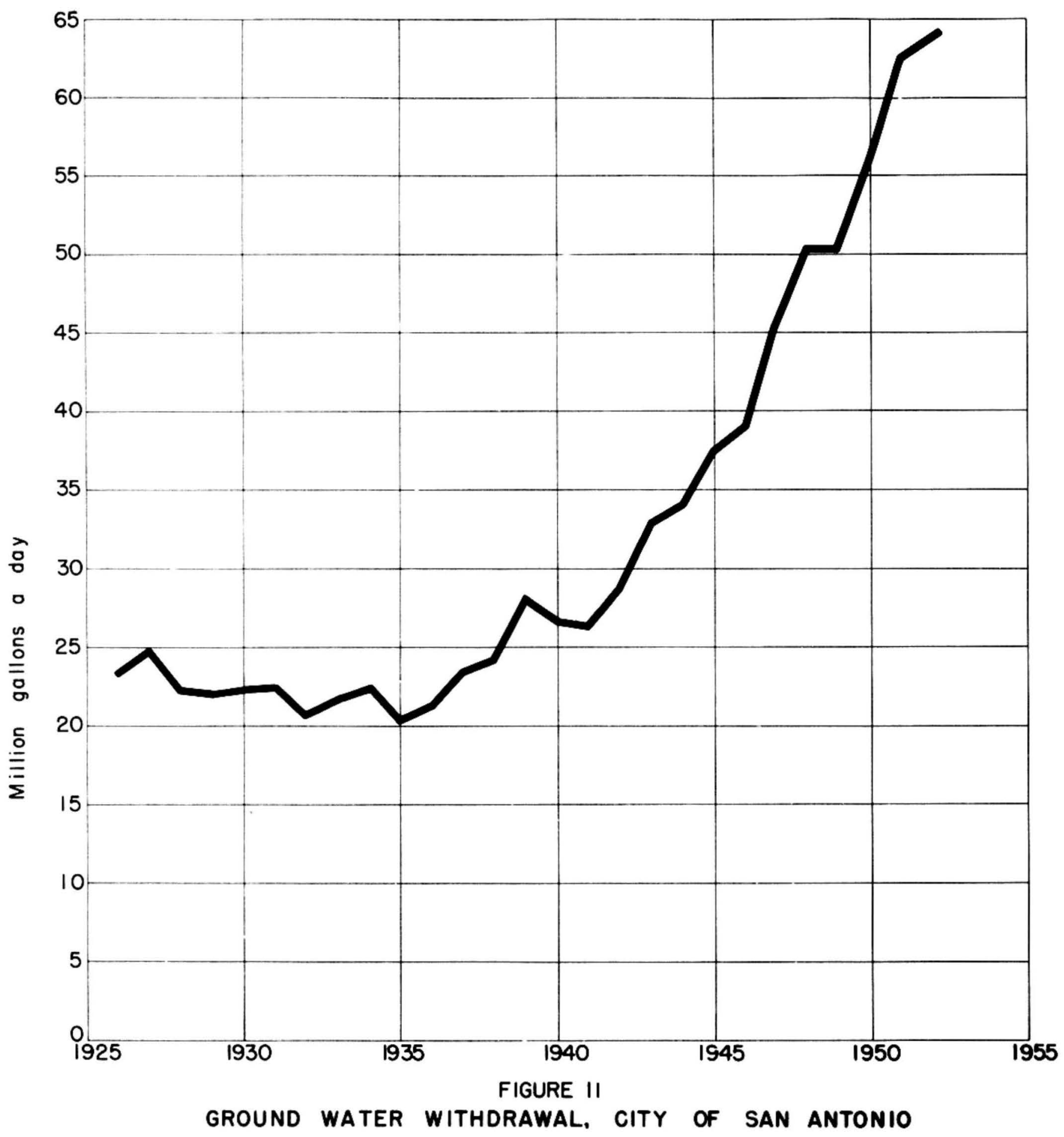


of turbidity of the water, and by the relation between water-level fluctuation in wells, rainfall, and the discharge of wells and springs Any engineering projects constructed in such a way as to alter the present rate of recharge to the Edwards limestone aquifer will have a direct effect on the perennial yield of ground water in the San Antonio area as well as elsewhere along the fault zone

During a 20-year period beginning in 1928 the stage of the artesian reservoir in the San Antonio area was in approximate equilibrium. The average rate of withdrawals in and around San Antonio was about 110 million gallons a day and Comal Springs had an average daily discharge of about 210 million gallons. Some additional water probably remained unaccounted for in other parts of Bexar County Thus it is estimated that. with average rainfall on favorable recharge localities the perennial yield of the reservoir in central Bexar County and an adjacent part of Comal County is not less than about 320 to 330 million gallons a day More recent information gathered during the present prolonged drought indicates the yield is less under conditions of extreme drought

In addition to the serious effects of the present drought a recent study of areas suitable for irrigation in Uvalde Medina and Bexar Counties indicates that irrigation from the same reservoir as that supplying San Antonio might be developed to such an extent that the irrigation requirements might be more than the surplus water passing San Antonio toward Comal Springs The city of San Antonio is aware of the problem and is engaged in water fact finding throughout areas from which it might appear feasible to obtain water for the city

Figure 12 shows the steady growth in the rate of use of ground water in El Paso. The city of El Paso as well as its military establishments and industries, is mindful of its water problem A survey and test-drilling program financed by the city of El Paso the Army, the Air Force, the Texas Board of Water Engineers, and the U. S. Geological Survey, covering about 800 square miles of the Hueco Bolson and Rio Grande Valley above El Paso, has recently been completed at a cost of more than $\$ 200,000$ Pribr to the survey. little was known about the areal extent of this ground-water reservoir north of El Paso, the chemical character of the ground water in the reservoir, and the approximate amount of water in storage in the reservoir The city of El Paso has known for some time that the rate of withdrawal from the ground-water reservoir has exceeded the rate of recharge to its well field in the Hueco Bolson Steps have been taken by the city to acquire water rights to additional ground water in storage outside the Hueco Bolson well field 
OTHER AREAS

Problems of the present and future ground-water supplies of other areas of Texas are not uncommon in areas other than the four just discussed Locally in parts of all the different ground-water areas west of the 30 -inch rainfail beit water is being removed at a greater rate than it is being replenished where heary development has taken place for irrigation public or industrial use The fact that ground water is being mined does not indicate that there is an immediate ground-water problem in all places. It is known that many hundreds of millions of acre-feet of usable ground water still remains in storage in some of our larger ground-water reservolrs It $1 \mathrm{~s}$ known also that in certain areas particularly in the lower Coastal Plain iarge reserves of ground water remain undeveloped

In looking ahead, I cannot stress too strongly the need for a clear, accurate appraisal of all the ground-water resources of Texas and the use of these appraisals in intelligent development. Texas is not only the second-ranking State in ground-water use it is one of the top-ranking States in total ground-water supply But only proper plan-* ning and proper development by those using ground water will assure the ultimate possible supply for the future 